\title{
Structural Diversity of Monoclonal CD4 Antibodies and Their Capacity to Block the HIV GP120/CD4 Interaction
}

\author{
WINFRIED WEISSENHORN, YING-HUA CHEN, CHRISTIAN REITER, CHRISTINE FEDERLE, \\ ELISABETH H. WEISS, GERT RIETHMÜLLER, and ERNST P. RIEBER
}

\begin{abstract}
A number of monoclonal antibodies have been raised against CD4, the receptor on $T$ cells for the HIV envelope glycoprotein gp120. In the present paper we describe biological activities and sequence analysis of seven CD4 MAb. Five of these MAb preparations compete with HIV/gp120 for CD4 binding. The sequences of the variable regions for these MAb were determined in order to ascertain any correlation with selective $V$ gene usage. A relationship was found between the expressed variable region genes and the CD4 recognition pattern. The $V_{H}$ genes that are used can be subdivided into two major groups expressing either a $V_{H}$ gene belonging to the J558 family or to the VGam family. The usage of the $V_{L}$ genes varies, indicating that the epitope specificity is predominantly determined by the rearranged $V_{H}$ genes. The distinct cross-reactivity pattern of these MAb also correlates with their capacity to block binding of recombinant gp120 to CD4 in vitro. Although five of these MAb were able to block gp120 binding none of the CDR sequences shows a relevant homology to the gp120 sequence. This indicates a steric hinderence mechanism for blocking gp120 binding and not a direct interaction with the receptor binding site on CD4. The data also confirm the failure of these MAb as a potential target for receptor mimicry.
\end{abstract}

\section{INTRODUCTION}

$\mathbf{T}$ HE UNIQUE FEATURE OF IMMUNOGLOBULINS is the enormous diversity of their variable region segments and their ability to interact with an unlimited number of determinants. The immunoglobulin (Ig) variable (V) regions are encoded by multiple DNA segments that rearrange during B cell differentiation $^{(1)}$ to form a complete variable region gene. Each heavy and light chain variable region is subdivided into four framework regions separated by three complementarity determining regions (CDR). The Ig V regions can be divided into families according to protein and nucleic acid similarities. In the murine systems there are a minimum of $11 \mathrm{~V}_{\mathrm{H}}$ and $29 \mathrm{VK}$ gene families. ${ }^{(2-6)}$ The structural basis of antibody complementarity and the origin of sequence diversification in $\mathrm{V}$ region genes have been studied in several systems. ${ }^{(7-13)}$ The results of these studies allowed a correlation of $\mathrm{V}$ region sequences with antigenbinding specificity.

The present paper reports $\mathrm{V}$ region sequences of seven CD4 MAb. The CD4 glycoprotein is predominantly found on the helper subset of $\mathrm{T}$ lymphocytes ${ }^{(14,15)}$ and of cells of the monocyte-macrophage lineage. ${ }^{(16,17)}$ In addition to its physiological function as a regulator of the immune system ${ }^{(18)} \mathrm{CD} 4$ serves also as a target for HIV attachment mediated by the viral envelope glycoprotein gp120.(19,20) The interaction has been mapped to the first Ig-like domain of CD4..$^{(21-23)}$ MAb directed to this region are potent inhibitors of HIV-replication and also of HIV-env-induced syncytium formation. It has been suggested that variable region determinants could imitate determinants on unrelated molecules. ${ }^{(24,25)}$ The analyzed CD4-specific MAb were raised to identify MAbs that were able to block the CD4$\mathrm{HIV/gp} 120$ interaction and thus allow the generation of potential anti-idiotype receptor antibodies.

The reported $\mathrm{V}$ region sequences of seven $\mathrm{CD} 4 \mathrm{MAb}$ can be subdivided into two groups represented by M-T310 and MT151. The heavy chains with closely related frameworks are combined with different $V_{\kappa}$ light chain genes of four $V_{\kappa}$ subgroups indicating that the epitope specificity is primarily determined by the $V_{H}$ region gene. Five of the analyzed CD4 MAb recognize epitopes that overlap the HIV/gpl20 binding site.

Institut für Immunologie, München, Germany. 
Three of the analyzed MAb seem to be closely related as they bind to the same or an overlapping epitope on the CD4 molecule. Mapping of the CD4 binding site for human immunodeficiency virus by mutagenesis identified amino acid residues that affect both the gp120-binding pattern and the reactivity of MAb M-T310 and M-T151. (26-28) The three-dimensional structure of the first and second domain of the CD4 molecule ${ }^{(29,30)}$ shows that the residues involved in M-T310 and M-T151 binding are stereoscopically separated, indicating the residues outside of the CDR2-like region of the CD4 molecule are also involved in the gpl20/CD4 interaction. The role of CD4-D1 CDR3-like loop in syncytium formation is controversial. ${ }^{(31-33)}$

\section{MATERIALS AND METHODS}

\section{Cell lines and $m A b s$}

The hybridomas M-T310, M-T404, M-T413, M-T408, MT321, M-T151, and M-T406 secreting CD4 MAb were obtained by fusion of $B A L B / c$ immune spleen cells to the nonsecreting myeloma line (X63) P3X63-Ag8.653 (American Type Culture Collection CRL 1580). Cells were grown in normal RPMI medium for DNA and RNA isolation and for amplification of hybridoma proteins in serum-free medium. Antibody purification was performed as described. ${ }^{(34)}$

\section{Inhibition of HIV-1 rgp120 binding}

Inhibition of HIV-1 gp120 binding by CD4 MAb was determined by an immunofluorescence assay: peripheral blood lymphocytes (PBL) $\left(2 \times 10^{5}\right)$ were preincubated with 3-fold dilutions of CD4 MAb starting from $30 \mu \mathrm{g} / \mathrm{ml}$ for $30 \mathrm{~min}$ on ice. The supernatant was removed and cells were incubated with recombinant gp120 (rgp120) for a further $20 \mathrm{~min}$ on ice. As a source for rgp 120 we used concentrated culture supernatant of gp120 secreting CHO transfectoma cell line ADP 240/17.1 made available by H.C. Holmes, MRC AIDS Reagent Project, London, GB. Bound rgp120 was detected with the specific biotinylated anti-gpl20 MAb 108, provided by D. Healey, MRC, London, UK, and fluorescein-conjugated streptavidin (Dianova, Hamburg, FRG). After fixing with $1 \%$ paraformaldehyde fluorescence intensity was quantified by FACScan analysis as fluorescence mean channel of living cells on log scale.

\section{Binding competition of $C D 4 \mathrm{mAb}$}

PBL were preincubated with purified CD4 MAb at $40 \mu \mathrm{g} / \mathrm{ml}$ for $60 \mathrm{~min}$ on ice. Cells were spun down and stained with a second biotinylated CD4 MAb for $30 \mathrm{~min}$ on ice, followed by a third incubation with fluorescein-conjugated avidin. Concentration of biotinylated MAb was selected to give threshold saturating staining without inhibitor. Staining intensity was measured by flow cytometry and the reduction of fluorescence mean channels was calculated compared to samples preincubated with unrelated CD MAb.

\section{Relative binding affinity of $C D 4 \mathrm{mAb}$}

Binding affinity of MAb M-T151 has been determined by Scatchard Plot. The relative binding affinities of all other analyzed MAb have been determined relative to MAb M-T151 with a value set at 1.0 . Briefly $10^{5}$ thymocytes were incubated with serially diluted $\mathrm{MAb}$ in $50 \mu \mathrm{l}$ tissue culture medium in microtiter wells for $20 \mathrm{~min}$ on ice. Cells were washed twice with ice cold PBS and stained with fluorescein-conjugated $\mathrm{F}\left(\mathrm{ab}^{\prime}\right)_{2}$ rabbit antimouse Ig.

Fluorescence mean channel determined by flow cytometry was plotted versus log CD4 MAb concentration resulting in sigmoid titration curves. The relative binding affinity was calculated from the distance between titration curves for MAb M$\mathrm{T} 151$ and respective antibodies.

\section{Syncytium inhibition assay}

The test was set up 10 times in flat-bottom microtiter plates; $0.5 \times 10^{5} \mathrm{C} 8166$ cells were incubated with serial dilution of CD4 MAb beginning with a concentration of $40 \mu \mathrm{g} / \mathrm{ml}$ in 100 $\mu$ l RPMI medium for $60 \mathrm{~min}$, then 1000 TCID $_{50}$ of HIV-1 strain MVP-899 was added for a culture period of 6 days. Formation of giant cells (syncytia) was visually controlled under an inverted microscope. As inhibition titer the lowest MAb concentration was given at which not more than one syncytium was detectable per well.

\section{Sequence analysis of immunoglobulin $\mathrm{mRNA}$}

Total RNA was prepared using standard methods. ${ }^{(35)}$ The RNA yield of $4 \times 10^{7}$ cells ( 300 to $400 \mu \mathrm{g}$ total RNA) was subjected to cDNA synthesis. The following synthetic oligonucleotide primers, which hybridize to immunoglobulin mRNA $3^{\prime}$ of the V-C junction, were synthesized by the phosphoramidite method with an Applied Biosystems Synthesizer and purified by polyacrylamide gel electrophoresis. The heavy chain oligonucleotide 5'-GGGGCCAGTGGATAGAC-3' cross-hybridized with $\gamma 1, \gamma 2 \mathrm{a}$, and $\gamma 2 \mathrm{~b}$ transcripts 21 bases $3^{\prime}$ from the V-C junction, whereas the light chain oligonucleotide 5'AGATGGATACAGTTGGT-3' cross-hybridized with $\kappa$ transcripts 38 bases $3^{\prime}$ of the $V_{\kappa}$ region. CDNA synthesis was performed with ${ }^{32} \mathrm{P}$-labeled oligonucleotides simultaneously on heavy and light chain mRNA as described. ${ }^{(7)}$ Full length cDNA copies of the $\mathrm{V}$ regions were fractionated on polyacrylamide gels, eluted from gel slices, and then sequenced according to the method of Maxam and Gilbert. ${ }^{(36)}$

\section{RESULTS}

\section{Binding specificity of CD4 $\mathrm{mAb}$}

Seven hybridomas secreting anti-CD4 MAb were obtained from six different fusions after immunization of different BALB/c mice with either cells from chronic lymphocytic leukemias of $\mathrm{T}$ type or transfectants of mouse P815 mastocytoma cells expressing human CD4. Only two MAb, M-T151 and M-T321, are derived from the same fusion. All MAb express a $\kappa$ light chain, five MAb use a $\gamma 1$, and two mAb a $\gamma 2 \mathrm{a}$ isotype for their heavy chain (Table 1). The binding competition analysis of seven CD4 MAb (Fig. 1) indicates an overall distribution into two roughly distinct groups. The assay shows further that MAb of the M-T310 group block each other more effectively than the members of the other group. This implies that M-T310, M-T404, and M-T413 recognize the same or an 
Table 1. Relative CD4 MAb Affinity and Interference WITH VIRUS (HIV) BINDING

\begin{tabular}{lrccc}
\hline & & $\begin{array}{c}\text { Relative } \\
\text { binding } \\
\text { affinity }\end{array}$ & $\begin{array}{c}\text { Total } \\
\text { inhibition } \\
\text { of rgp120 } \\
\text { binding }\end{array}$ & $\begin{array}{c}\text { Inhibition } \\
\text { of HIV-1 } \\
\text { MVP-899 } \\
\text { infection }^{c}\end{array}$ \\
\hline M-T310 & $\gamma 1 / \kappa$ & 8.2 & 0.3 & $0.03-0.1$ \\
M-T404 & $\gamma 1 / \kappa$ & 6.1 & 0.3 & $1.0-3.0$ \\
M-T413 & $\gamma 1 / \kappa$ & 8.6 & 0.1 & 0.03 \\
M-T408 & $\gamma 1 / \kappa$ & 0.3 & 10.0 & - \\
M-T151 & $\gamma 2 \mathrm{a} / \kappa$ & 1.0 & 10.0 & 3.0 \\
M-T321 & $\gamma 1 / \kappa$ & 0.6 & - & - \\
M-T406 & $\gamma 2 \mathrm{a} / \kappa$ & 0.9 & - & - \\
\hline
\end{tabular}

${ }^{a}$ The binding affinity of CD4 MAb relative to MAb M-T151.

${ }^{b} \mathrm{MAb}$ concentration $(\mu \mathrm{g} / \mathrm{ml})$ at which binding of HIV rgp 120 is totally reduced on the basis of log scale fluorescence intensity.

'The minimum MAb concentration ( $\mu \mathrm{g} / \mathrm{ml})$ required to completely block infection and syncytium formation in $1 \times 10^{5}$ C8166 cells after challenge with 1000 TCID $_{50}$ of HIV-1 MVP899 strain (-, no inhibition at $20 \mu \mathrm{g} / \mathrm{ml}$ ).

overlapping epitope on the CD4 molecule. M-T408 may have contacts to both antigenic regions recognized by the two groups, as this MAb blocks all analyzed MAb except M-T321 and M$\mathrm{T} 151$. The binding competition of the M-T151 group members is not as stringent as for M-T310 group members, which might be in part explained by their large differences in affinity. But they could also recognize different epitopes or only structurally overlapping or neighboring epitopes.

The relative binding affinity of MAb and their interference with HIV-1 binding is shown in Table 1. The inhibition of rgp 120 binding and HIV-1 infection in vitro correlates with the CD4 binding pattern. Only M-T310, M-T404, and M-T413 with an identical cross-blocking pattern also interfere effectively in low concentrations with rgp 120 binding and HIV-1 infection

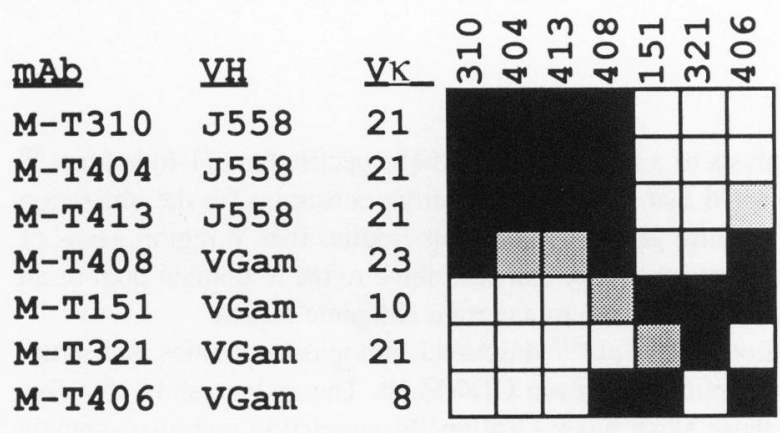

FIG. 1. Binding competition analysis of CD4 MAb is shown as the reduction of fluorescence mean channel, measured by flow cytometry. The reduction of fluorescence mean channel is indicated as follows: open squares: $<59$; gray stippled squares: 60-119; dark stippled squares: $120-179$; black squares: $>180$. The $V_{H}$ and $V_{\kappa}$ gene families from which the $V$ regions were derived are indicated. The hybridomas have been placed into sets that use the same or similar V genes, and that display similar reactivity patterns. in vitro. In the second group according to the $\mathrm{V}_{\mathrm{H}}$ gene usage only MAb M-T151 and M-T408 show total inhibition of rgp120 binding in a 3- to 10-fold higher concentration than members of the M-T310 group. The relative CD4 binding affinity of members of the M-T151 group is also reduced by a factor 3 to 10 in comparison to MAb of M-T310 group. Moreover only MAb M-T151 inhibits HIV-1 infection in vitro. These assays on interference with HIV-1 binding show that five of the MAb recognize epitopes that interfere with the HIV binding site on the CD4 molecule.

\section{Heavy chain analysis}

Sequence analysis of the CD4 MAb showed that productive $V_{H}$ region genes can be attributed to two different $V_{H}$ gene families. The gene families comprise groups of related $V$ genes that in general share greater than $80 \%$ sequence similarity. The $V_{H}$ region genes of MAb M-T310, M-T404, and M-T413 are members of the largest $\mathrm{V}$ gene family $\mathrm{J} 558$ and the $\mathrm{V}_{\mathrm{H}}$ region genes of mAb M-T151, M-T321, M-T406, and M-T408 are members of the VGam gene family (Fig. 2). The few sequence differences of M-T310, M-T404, and M-T413 $\mathrm{V}_{\mathrm{H}}$ region genes indicate that they are very closely related members of a gene family. They share at least $92.9 \%$ homology among themselves. The $\mathrm{V}_{\mathrm{H}}$ region sequences of the second group are all very


homology among themselves.

In contrast to the sequence similarity displayed by the $V_{H}$ regions, the $\mathrm{D}$ regions used in the hybridomas of related specificity exhibit a marked diversity both in sequence and length. The diverse nature of these sequences does not allow a precise determination of $\mathrm{V}_{\mathrm{H}}-\mathrm{D}$ and $\mathrm{D}-\mathrm{J}_{\mathrm{H}}$ boundaries. Although none of these somatic $\mathrm{D}$ regions corresponds exactly to identified germline D segments ${ }^{(37)}$ they all show regions of homology flanked by relatively $\mathrm{G}$-rich sequences ( $\mathrm{N}$ sequences) that previously have been proposed to be inserted during $\mathrm{V}_{\mathrm{H}}-\mathrm{D}$ and $\mathrm{D}$ $\mathrm{J}_{\mathrm{H}}$ joining events. ${ }^{(38)}$ The overall length of the $\mathrm{D}$ regions varies from 24 to 36 nucleotides, showing preferential homology to members of DSP2 and DFL16 D region gene segments (Fig. 2). The analyzed $V_{H}$ members of the M-T310 group show a $D$ $\mathrm{J} 3$ rearrangement, while the $\mathrm{V}_{\mathrm{H}}$ gene members of the M-T151 group have conveyed their D rearrangements to $\mathrm{J} 2, \mathrm{~J} 3$, and $\mathrm{J} 4$. In addition, no sequence homology in the CDR of either heavy or light chain to the gp120 sequence has been found.

\section{Light chain analysis}

The nucleotide and deduced amino acid sequences of seven different CD4-specific $\mathrm{L}$ chain variable regions are shown in Figure 3 . The $\mathrm{V}$ region sequences can be subdivided into four different subgroups according to their homology $(>80 \%)$ to the 16 or 18 different Vk gene families. ${ }^{(4-6)}$ The MAb M-T310, MT404, M-T413, and M-T321 use V region genes homologous to members of the subgroup 21 . The high sequence homology of 89.3 to $100 \%$ among these $V_{L}$ regions indicates that these $V$ genes are closely related. The differences in sequence could be explained by somatic mutation. MAb M-T408 uses a $V_{L}$ region homologous to members of the $\mathrm{V}_{\kappa}$ subgroup. ${ }^{(23)}$ MAb M-T406 has a $V_{L}$ region gene member of the subgroup 8 and MAb $M$ $\mathrm{T} 151$ a member of the subgroup 10 rearranged. All $\mathrm{V}_{\kappa}$ regions used by the analyzed MAb rearranged to either $\mathrm{J} 1$ or $\mathrm{J} 2$. 


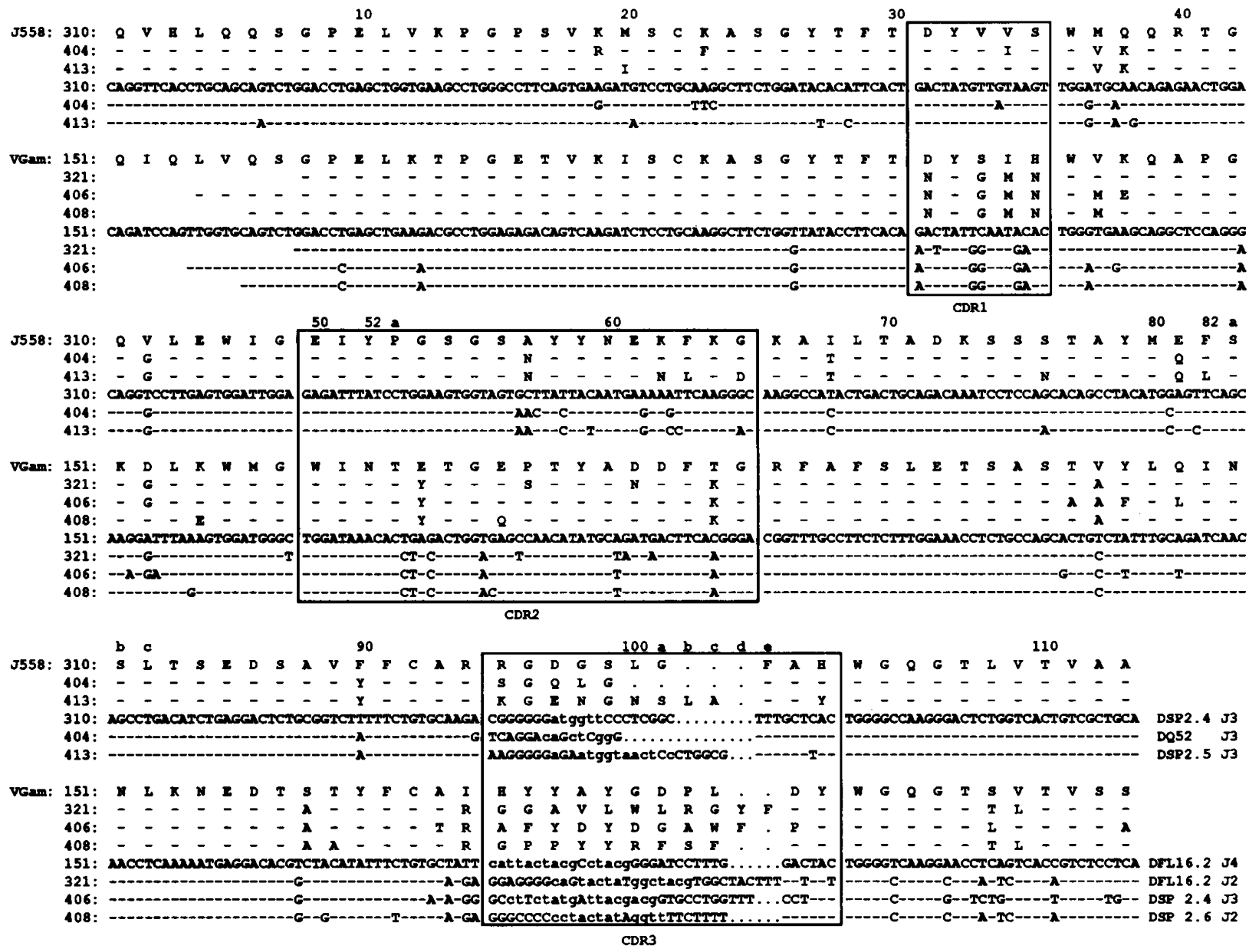

FIG. 2. Nucleotide sequence and deduced amino acid sequence alignment of the $V_{H}$ regions of seven MAb to CD4. Sequences are grouped according to the indicated $V_{H}$ gene families, and are displayed relative to a representative from each group. The deduced amino acid sequences are numbered according to Kabat et al., ${ }^{(4)}$ and the locations of CDR are shown. The symbol (-) corresponds to the same amino acid or nucleotide and the symbol (O) represents a gap in comparison to the representative sequence. The used $\mathrm{J}$ and $\mathrm{D}$ sequence elements are indicated at the end. Nucleotides homologous to known D segments are shown in small letters. These nucleotide sequences and those shown in Figure 3 have been submitted to the EMBL GenBank and DDBJ Nucleotide Sequence Databases and assigned accession numbes X65084-X65097. Sequences encoding $V_{H}$ and $V_{\kappa}$ regions of MAb M-T310 and M-T151 have been published. ${ }^{(57)}$

\section{DISCUSSION}

The sequence of the heavy and light chain variable regions of seven CD4 MAb was determined to ascertain whether structural features are shared by antibodies that recognize CD4 and interfere with gp120/CD4 recognition. This analysis revealed homology between $\mathrm{V}_{\mathrm{H}}$ gene segments, and allowed their distribution into two groups. Members of the two families show a similar reactivity pattern, indicating that they recognize the same or a structurally overlapping epitope.

The correlation of $\mathrm{V}$ usage with binding specificity has been described for other antigens including influenza virus hemagglutinin, ${ }^{(7)}$ digoxin, ${ }^{(10)}$ cyclosporin $A,{ }^{(12)}$ and the antibody response to the Haemophilus influenzae type B capsular polysaccharide. ${ }^{(13)}$ Extensive examinations of the antibody response to antigenic regions on the influenza hemagglutinin ${ }^{(39)}$ and the analysis of a large panel of MAb specific for $\alpha(1-6)$ dextran $^{(40)}$ revealed that there is no apparent constraint for the utilization of specific gene families. This implies that $\mathrm{V}$ region genes of nearly every family can contribute to the $V$ domain pool of an antibody response to a certain antigenic region.

Lohman et al. ${ }^{(41)}$ described biological activities and structural features of seven CD4 MAb. The authors show that five of these MAb block CD4/gp120 interaction and also syncytia formation efficiently. In this context it is remarkable that the sequence analysis reveals that the $\mathrm{V}$ region $\kappa$ chain from each of the seven MAb is encoded by the $\mathrm{V} \kappa 21$ gene family. Six of the MAb use a $V_{H}$ gene region encoded by the J558 gene family and one MAb uses a member of the VGam gene family. In addition to the high sequence homology in the $\mathrm{V}$ gene regions, MAb M-T310 and MAb Leu3a also show a high degree of amino acid sequence homology in the $V_{H}$ CDR3 region en- 
coded by $\mathrm{D}$ minigenes. According to the biological activities and the shared structural features we conclude that at least MAb M-T310, M-T413, and M-T404, which all block binding of Leu3a to CD4 in a cross-blocking experiment (data not shown), recognize the same or an overlapping epitope on the CD4 molecule. Although by analyzing a larger panel of hybridomas secreting CD4 MAb with rgp120 cross-blocking capacity one might find usage of more different $\mathrm{V}$ gene families, it indicates a structural and functional restricted antibody response to this defined antigenic region on the CD4 molecule.

The distinct specificity of the analyzed MAb is influenced by $V_{H} C D R 3$, which differs in sequence and in length, leading to perhaps different contacts to the CD4 molecule. The closely related binding specificity of the M-T310 group members may also be supported by the usage of homologous $V_{L}$ gene segments. The usage of $V_{L}$ gene segments in the M-T151 group is more heterogeneous. In this case not only CDR3 but also the light chain $\mathrm{V}$ region might contribute to differences in fine specificity. Studies on MAb specific for hemagglutinin ${ }^{(7,39)}$ and lysozyme ${ }^{(42)}$ revealed that $V_{H}$ gene segments combined with different $V_{L}$ gene segments can have the same epitope specificity. It has been suggested that the combination of $V_{H}$ with any $V_{L}$ that allows formation of the combining site without creating unfavorable steric or electrostatic interactions should preserve a significant portion of antibody specificity. ${ }^{(43)}$ Thus, the antigen-binding specificity directed by $\mathrm{V}_{\mathrm{H}}$ is preserved. This view is further supported by the result of Kabat and $\mathrm{Wu}{ }^{(44)}$ who examined a large database of amino acid sequences of antibodies with various specificities. They found many antibodies of distinctly different specificities assemble identical $V_{L}$ domains with different $\mathrm{V}_{\mathrm{H}}$ domains. Moreover, this may hold true for the members of the M-T151 group, which all use $V_{L}$ gene
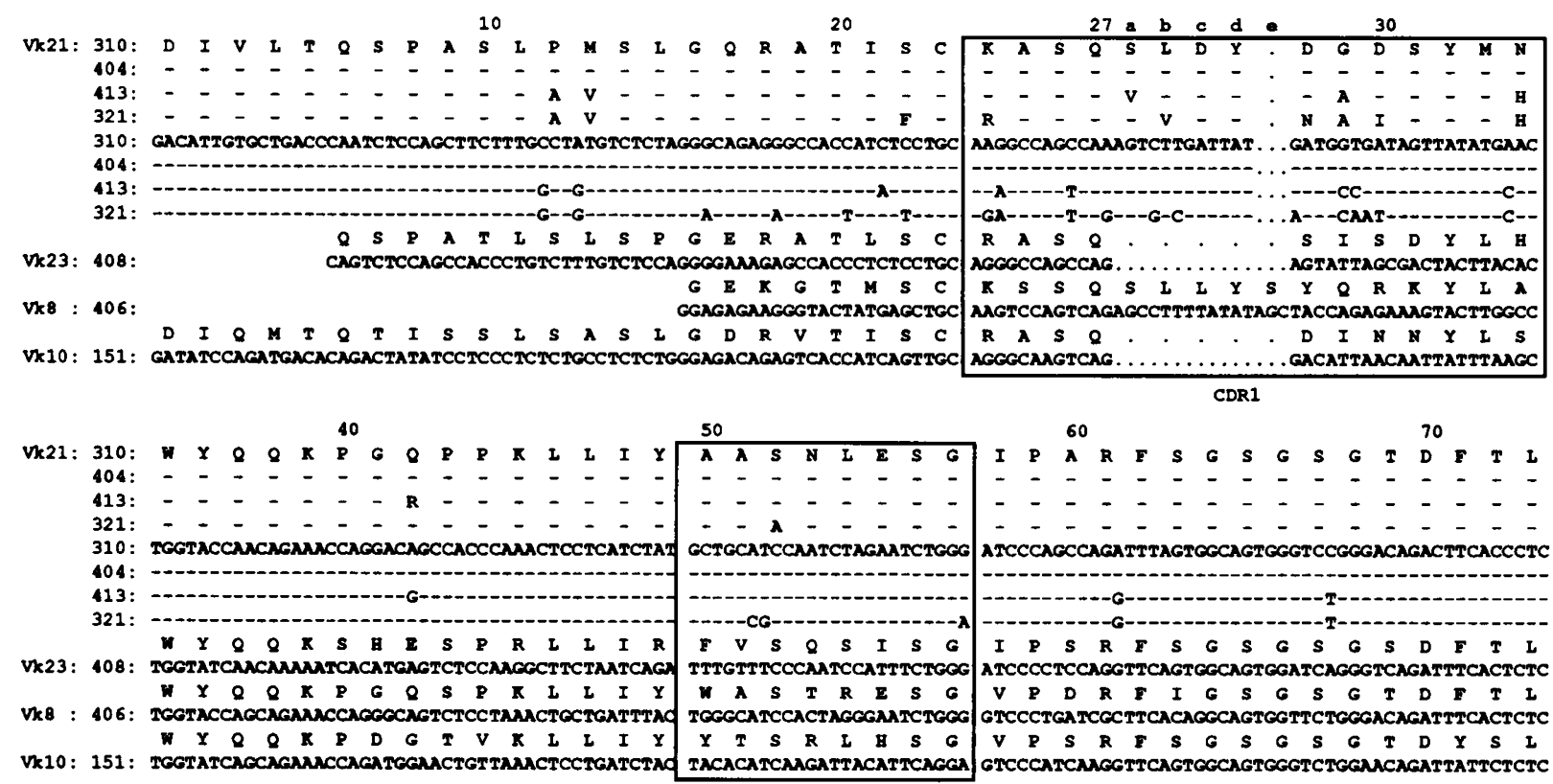

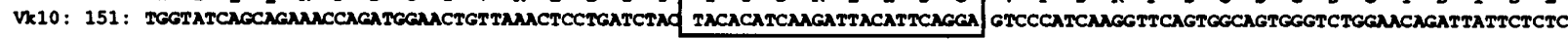



FIG. 3. Nucleotide sequence and deduced amino acid sequence alignment of the $\mathrm{V} \kappa$ regions of seven MAb to CD4. Sequences are grouped according to the indicated $\mathrm{V} \kappa$ gene families, and are displayed relative to a representative from each group. The deduced amino acid sequences are numbered according to Kabat et al., ${ }^{(4)}$ and the locations of CDR are shown. The symbol ( - ) corresponds to the same amino acid or nucleotide and the symbol (O) represents a gap in comparison to the representative sequence. The used $\mathrm{J}$ sequence elements are indicated at the end. 
segments homologous to different Vk subgroups. This may also hold true for the usages of a very similar $\mathrm{V}_{\mathrm{L}}$ domain by $\mathrm{M}$ T321 and the members of the M-T310 $\mathrm{V}_{\mathrm{H}}$ gene family.

The CD4 binding specificities of MAb M-T310, M-T321, and M-T151 have been characterized by several groups. CD4 specific amino acids 42 and 43 are involved in binding of MAb M-T310, whereas for MAb M-T321 positions 17, 24, 25, 88, and 89 and for MAb M-T151 amino acids 1, 72, 94, 95, and 165 are critical for antibody-antigen interaction. ${ }^{(26-28)}$ By the same approach the gp1 20 binding site was mapped to the N-terminal domain 1 (D1) of CD4. Mutation of 19 amino acids in CD4-D1 seem to have an impact on gp120 binding without apparent global conformational changes. ${ }^{(26-28,45,46)}$ Thirteen of these residues are in the CDR2-like segment (aa 38 to 59). Four locations outside this sequence (aa 29, $59-64,77-81$, and 85 ) were also identified as potential contact sites. ${ }^{(47)}$ These studies suggest that residues recognized by M-T310 and probably also by M-T404 and M-T413 are shared with the gp120 binding site. MAb M-T151 and M-T408 of the second group do not show the same stringent inhibition of rgp120 binding, and only M-T151 can inhibit viral infection in vitro. This may be due to the lower affinity relative to the other MAb analyzed and thus allows a displacement by viral gp120. The gp 120 binding constant for CD4 has been found to be $4 \times 10^{-9} \mathrm{M}$ for the HIV-IIIB isolate. ${ }^{(48)}$ Another explanation would be that these MAb do not interact directly with residues of the CD4 molecule identified to interact with gp120. They might recognize epitope(s) within this region and thus lead to sterical inhibition of CD4/gp120 interaction, which again might depend on their affinity.

As a third possibility the binding of CD4 MAb could induce conformational changes in a distant region of the CD4 molecule, thus influencing the gp120 interaction. Truneh et al. ${ }^{(49)}$ suggested that the CDR2 and CDR3-like region of CD4-D1 might be sequentially engaged in the binding of different interaction sites on the gp120 glycoprotein. This study supports this view that not only the CDR2-like region of CD4-D1 is involved in CD4/gp120 interaction. The epitope(s) recognized by MAb of the M-T310 group do not interfere with the M-T151 epitope, but both block binding of rgpl 20 and inhibit infection of HIV-1 in vitro. Conformational changes induced by these MAb can be excluded as thymocytes can be stained by MAb M-T310 together with MAb M-T151 in a double fluorescence (data not shown).

The CDR2-like loop in CD4-D1 as the major binding site for gp120 may interact with a compact, highly conserved binding pocket in gp120. Theoretically, an anti-idiotypic CD4 MAb, whose epitope closely resembles the CD4 binding site of gp120, may be a better immunogen than gp120 itself and may elicit antibodies that would outcompete the high affinity virus-receptor interaction. However, immunization of mice with MAb M-T310 elicited an anti-idiotype response that does not interfere with CD4/gp120 interaction. ${ }^{(50)}$ Also anti-idiotypes specific for MAb Leu3a only weakly neutralized HIV. ${ }^{(51)}$ An analysis of a panel of $225 \mathrm{CD} 4 \mathrm{MAb}$ showed only for one MAb fine specificity that was broadly like that of gp120.(52) In contrast to these studies others described anti-idiotypic antibodies raised against CD4 MAb, which showed gp120-specific activity. ${ }^{(53,54)}$

It has been shown that antireceptor antibodies might share sequence homologies in their CDR to the ligand. ${ }^{(55,56)}$ This is not the case for either our analysed CD4 MAb or the ones described by Lohman et al. ${ }^{(41)}$ The data also confirm the failure of these MAb for being a potential target for the concept of mimicry between antibodies and receptors.

\section{ACKNOWLEDGMENTS}

This work was supported by a grant from the Genzentrum München and the BMFT-AIDS-Programm, Verbundprojekt München I.

\section{REFERENCES}

1. Tonegawa S: Somatic generation of antibody diversity. Nature (London) 1983;302:575-581.

2. Brodeur $P$, and Riblet $R$ : The immunoglobulin heavy chain variable region locus in the mouse, one hundred Igh- $\mathrm{V}$ genes comprise seven families of homologous genes. Eur J Immunol 1984; 14:922-930.

3. Winter E, Radbruch A, and Krawinkel U: Members of novel VH families are found in VDJ regions of polyclonally activated B lymphocytes. EMBO J 1985;4:2861-2867.

4. Kabat EA, Wu TT, Reid-Müller M, Perry HM, and Gottesmann KS: Sequences of Proteins of Immunological Interest, 4th ed. U.S. Department of Health and Human Services, National Institutes of Health, Bethesda, MD, 1987.

5. Kofler R, Duchosal MA, and Dixon FJ: Complexity, polymorphism, and connectivity of mouse $\mathrm{Vk}$ gene families. Immunogenetics 1989;29:65-74.

6. Strohal R, Helmberg A, Kroemer G, and Kofler R: Mouse Vk gene classification by nucleic acid sequence similarity. Immunogenetics 1989;30:475-493.

7. Caton AJ, Brownlee GG, Staudt LM, and Gerhard W: Structural and functional implications of a restricted antibody response to a defined antigenic region on the influenza virus hemagglutinin. EMBO J 1986;5:1577-1587.

8. Kaartinen M, Griffith GM, Markham AF, and Milstein C: mRNA sequences define an unusually restricted IgG response to 2-phenyloxazolone and its early diversification. Nature (London) 1983;304:320-324.

9. Berek C, and Milstein C: Mutation drift and repertoire shift in the maturation of the immune response. Immunol Rev 1987;96:23-41.

10. Panka DJ, and Margolies MN: Complete variable region sequences of five homologous high affinity anti-digoxin antibodies. J Immunol 1987;139:2385-2391.

11. Sherman MA, Deans RJ, and Bolger MD: Haloperidol binding to monoclonal antibodies. Hypervariable region amino acid sequence determination. J Biol Chem 1988;263:4059-4063.

12. Schmitter D, Poch O, Zeder G, Heinrich GF, Kocher HP, Quesniaux VFJ, and van Regenmortel MHV: Analysis of the structural diversity of monoclonal antibodies to cyclosporine. Mol Immunol 1990;27:1029-1038.

13. Adderson EE, Shackelford PG, Quinn A, and Carroll WL: Restricted IgH chain $\mathrm{V}$ gene usage in the human antibody response to Haemophilus influenzae type b capsular polysaccharide. J Immunol 1991;147:1667-1674.

14. Reinherz EL, Kung PC, Goldstein G, and Schlossman SF: Separation of functional subsets of human $\mathrm{T}$ cells by a monoclonal antibody. Proc Natl Acad Sci USA 1979;76:4061-4065.

15. Reinherz EL, and Schlossman SF: The differentiation and function of human T lymphocytes. Cell 1980;19:821-827.

16. Stewart SJ, Fujimoto J, and Levy R: Human T lymphocytes and monocytes bear the same Leu-3(T4) antigen. J Immunol 1986;136:3773-3778. 
17. Maddon PJ, Molineaux SM, Maddon DE, Zimmerman KA, Godfrey M, Alt FW, Chess L, and Axel R: Structure and expression of the human and mouse T4 genes. Proc Natl Acad Sci USA 1987;84:9155-9159.

18. Janeway CA Jr, Carding S, Jones B, Murray J, Portoles P, Rasmussen R, Rojo J, Saizawa K, Wast J, and Bottomly K: CD4+ T cells: Specificity and function. Immunol Rev 1988;101: 39-80.

19. Dalgleish AG, Beverley PCL, Clapham PR, Crawford DH, Greaves MF, and Weiss RA: The CD4 (T4) antigen is an essential component of the receptor for the AIDS retrovirus. Nature (London) 1984;312:763-767.

20. Klatzmann D, Champagne E, Chamaret S, Gruest J, Guetard D, Hercend T, Gluckman JC, and Montagnier L: T lymphocyte T4 molecule behaves as the receptor for human retrovirus LAV. Nature (London) 1984;312:767-768.

21. Landau NR, Warton M, and Littman DR: The envelope glycoprotein of the human immunodeficiency viruses HIV-1 and HIV-2 and SIV interact with similar epitopes on their cellular receptors, the CD4 molecule. Nature (London) 1988;334:159-162.

22. Richardson NE, Brown NR, Hussey RE, Vaid A, Matthews TJ, Bolognesi DP, and Reinherz EL: Binding site for human immunodeficiency virus coat protein gp120 is located in the NH2-terminal region of $\mathrm{T} 4(\mathrm{CD} 4)$ and requires the intact variable-region-like domain. Proc Natl Acad Sci USA 1988;85:6102-6106.

23. Arthos JK, Deen C, Chaikin MA, Fornwald JA, Sathe G, Sattentau QJ, Clapham PR, Weiss RA, McDougal JS, Pietropaolo C, Axel R, Truneh A, Maddon PJ, and Sweet RW: Identification of the residues in human $\mathrm{CD} 4$ critical for the binding of HIV. Cell 1989;57:469-481.

24. Lindenmann J: Speculations on idiotypes and homobodies. Ann Immunol (Paris) 1973;124:171-184.

25. Jerne NK: Towards a network theory of the immune systems. Ann Immunol (Paris) 1974;125:373-389.

26. Peterson A, and Seed B: Genetic analysis of monoclonal antibody and HIV binding sites on the human lymphocyte antigen CD4. Cell 1988;54:65-72.

27. Sattentau QJ, Arthos J, Deen K, Hanna N, Healey D, Beverly PCL, Sweet $R$, and Truneh A: Structural analysis of the human immunodeficiency virus binding domain of CD4. J Exp Med 1988; 170:1319-1334.

28. Ashkenazi A, Presta LG, Marsters SA, Camerato TR, Rosenthal KA, Fendly BM, and Capon DJ: Mapping the CD4 binding site for human immunodeficiency virus by alanine-scanning mutagenesis. Proc Natl Acad Sci USA 1990;87:7150-7154.

29. Ryu SE, Kwong PD, Truneh A, Porter TG, Arthos J, Rosenberg M, Dai X, Xuong N, Axel R, Sweet RW, and Hendrickson WA: Crystal structure of an HIV binding recombinant fragment of human CD4. Nature (London) 1990;348:419-425.

30. Wang J, Yan Y, Garrett TPJ, Liu J, Rodgers DW, Garlick RL, Tarr GE, Husain Y, Reinherz EL, and Harrison ST: Atomic structure of a fragment of human CD4 containing two immunoglobulin like domains. Nature (London) 1990;348:411-418.

31. Camerini D, and Seed B: A CD4 domain important for HIV-mediated syncytium formation lies outside the virus binding site. Cell 1990;60:747-754.

32. Corbeau P, Benkirane M, Weil R, David C, Emiliani S, Olive D, Mawas C, Serre A, and Devaux C: Ig CDR3-like region of the CD4 molecule is involved in HIV-induced syncytia formation but not in viral entry. J Immunol 1993;150:290-301.

33. Broder CC, and Berger EA: CD4 molecules with a diversity of mutations encompassing the CDR3 region efficiently support human immunodeficiency virus type 1 envelope glycoprotein mediated cell fusion. J Virol 1993;67:913-926.

34. Prinz JC, and Rieber EP: Fc-receptors for IgE on human lymphocytes. Detection with a rosetting assay using a recombinant hu- man/mouse IgE antibody and characterization with monoclonal antibodies. Hybridoma 1987;6:1-16.

35. Chirgwin JM, Przybyla AE, MacDonald AJ, and Rutter WJ: Isolation of biologically active ribonucleic acid from sources enriched in ribonuclease. Biochemistry 1979;18:5294-5299.

36. Maxam AM, and Gilbert W: A new method for sequencing DNA. Proc Natl Acad Sci USA 1977;74:560-564.

37. Kurosawa $\mathrm{Y}$, and Tonegawa S: Organization, structure and assembly of immunoglobulin heavy chain diversity DNA segments. J Exp Med 1982; I55:201-218.

38. Alt F, and Baltimore D: Joining of immunoglobulin heavy chain segments: Implications from a chromosome with evidence of three D-JH fusions. Proc Natl Acad Sci USA 1982;79: 4118-4122.

39. Caton AJ, Stark S, Kavaler J, Staudt LM, Schwartz D, and Gerhard W: Many variable region genes are utilized in the antibody response of $B A L B / c$ mice to the influenza virus $A / P R / 8 / 34$ hemagglutinin. J Immunol 1991;147:1675-1686.

40. Wang D, Liao J, Mitra D, Akolkar PN, Gruezo F, and Kabat EA: The repertoire of antibodies to a single antigenic determinant. Mol Immunol 1991;28:1387-1397.

41. Lohman KL, Attanasio R, Buck D, Carrillo MA, Allan JS, and Kennedy RC: Characteristics of murine monoclonal anti-CD4. J Immunol 1992;149:3247-3253.

42. Smith-Gill SJ, Hamel PA, Lovoie ThB, and Dorrington KJ: Contributions of immunoglobulin heavy and light chains to antibody specificity for lysozyme and two haptens. J Immunol 1987;139:4135-4144.

43. Tainer JA, Deal CD, Geysen MH, Roberts VA, and Getzoff ED: Defining antibody-antigen recognition: Towards engineered antibodies and epitiopes. Int Rev Immunol 1991;7:165-188.

44. Kabat EA, and Wu TT: Identical V region amino acid sequences and segments of sequences in antibodies of different specificities. J Immunol 1991;147:1709-1719.

45. Arthos J, Deen KC, Chaikin MA, Fornwald JA, Sarhe G, Sattentau QJ, Clapham PR, Weiss RA, McDougal JS, Pietro-Paolo C, Axel $\mathrm{R}$, Truneh A, Maddon PJ, and Sweet RW: Identification of residues in human CD4 critical for the binding of HIV. Cell 1989;57:469-481.

46. Brodsky MH, Warton M, Myers RM, and Littman DR: Analysis of the site in CD4 that binds to the HIV envelope glycoprotein. J Immunol 1990;144:3078-3086.

47. Capon DJ, and Ward RHR: The CD4-gp120 interaction and AIDS pathogenesis. Annu Rev Immunol 1991;9:649-678.

48. Lasky L, Nakamura G, Smith DH, Fennie C, Shimasaki C, Patzer E, Berman P, Gregory T, and Capon DJ: Delineation of a region of the human immunodeficiency virus type 1 gp120 glycoprotein critical for interaction with the CD4 receptor. Cell 1987; 50:975-985.

49. Truneh A, Buck D, Cassatt DR, Juszczak R, Kassis S, Ryu SE, Healey D, Sweet R, and Sattentau Q: A region in domain 1 of CD4 distinct from the primary gp120 binding site is involved in HIV infection and virus-mediated fusion. J Biol Chem 1991;266: 5942-5948.

50. Weissenhorn W, Chen YH, Riethmuller G, Rieber EP, and Weiss $\mathrm{EH}: \mathrm{V}_{\mathrm{H}}$ related idiotopes detected by site-directed mutagenesis: $A$ study induced by the failure to find CD4 anti-idiotypic antibodies mimicking the cellular receptor of HIV. J Immunol 1992;149:1237-1241.

51. Dalgleish AG, Thomson BJ, Chanh TC, Malkovsky M, and Kennedy RC: Neutralisation of HIV isolates by anti-idiotypic antibodies which mimic the T4 (CD4) epitope: A potential aids vaccine. Lancet 1987;II:1047-1050.

52. Davies SJ, Schockmel GA, Somoza C, Buck DW, Healey DG, Rieber EP, Reiter C, and Williams A: Antibody and HIV-I gp120 recognition of $\mathrm{CD} 4$ undermines the concept of mimicry between antibodies and receptors. Nature (London) 1992;358:76-79. 
53. Sutor GC, Dreikhausen U, Vahning U, Jurkiewicz E, Hunsmann G, Lundin K, and Schedel I: Neutralization of HIV-1 by anti-idiotypes to monoclonal anti-CD4. J Immunol 1992;149:1452-1461.

54. Karpatkin S, Nardi MA, Liu LX, Kouri YH, and Borkowsky W: Production of a human anti-CD4 monoclonal antibody with anti idiotypic to anti-HIV type 1 glycoprotein 120. AIDS Res Hum Retroviruses 1995;11:509-515.

55. Bruck C, Co MS, Slaoui M, Gaulton GN, Smith T, Fields BN, Mullins JI, and Greene MI: Nucleic acid sequence of an internal image bearing monoclonal anti-idiotype and its comparison to the sequence of the external antigen. Proc Natl Acad Sci USA 1986;83:6578-6582.

56. Taub R, Hsu JC, Garsky VM, Hill BL, Erlanger BF, and Kohn LD: Peptide sequence from the hypervariable regions of two monoclonal anti-idiotypic antibodies against the thyrotropin TSH receptor are similar to TSH and inhibit TSH increased cAMP production in FRTL-5 thyroid cells. J Biol Chem 1992;267:5977-5984.

57. Weissenhorn W, Scheuer W, Kaluza B, Schwirzke M, Reiter C, Flieger D, Lenz H, Weiss EH, Rieber EP, Riethmuller G, and
Weidle UH: Combinatorial effect of two chimeric antibodies directed to human CD4 and of one chimeric antibody directed to the $\alpha$ chain of the human interleukin-2 receptor. Gene 1992; 121:271-278.

Address reprint requests to: Winfried Weissenhorn

Howard Hughes Medical Institute

The Children's Hospital, Enders 673

320 Longwood Avenue

Boston, MA 02115

Ernst P. Rieber

Institut für Immunologie

Postfach 800115

D-01101-Dresden, Germany

Received for publication December 20, 1995. Accepted January 10, 1996. 
This article has been cited by:

1. Thomas Kirschbaum, Soheil Pourrajabi, Ines Zocher, Jürgen Schwendinger, Verena Heim, Franz Röschenthaler, Verena Kirschbaum, Hans G. Zachau. 1998. The 3' part of the immunoglobulin $x$ locus of the mouse. European Journal of Immunology 28:5, 1458-1466. [CrossRef] 